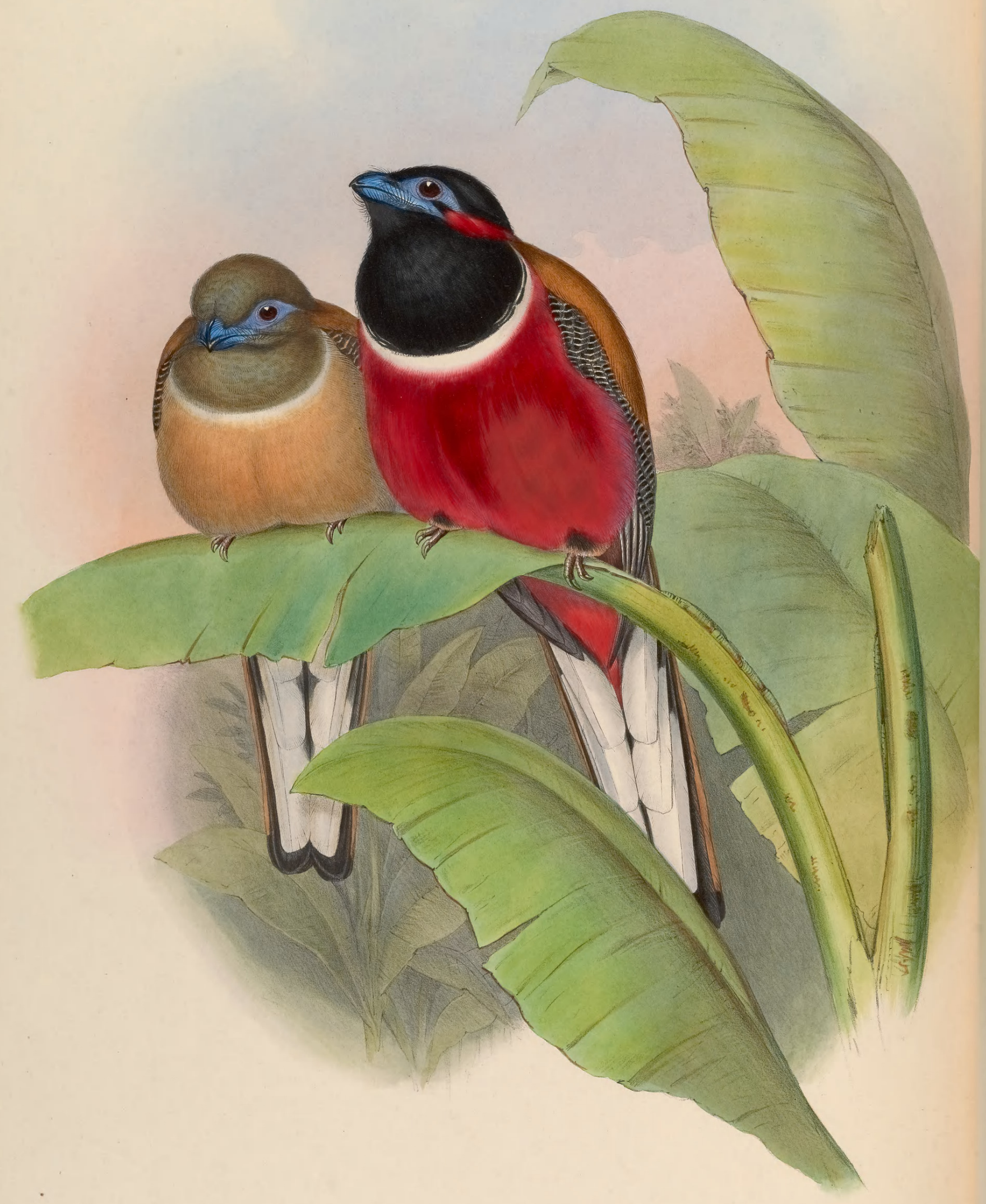

HARPACTES IKASUNBA. 


\section{HARPACTES KASUMBA.}

\section{Kasumba Trogon.}

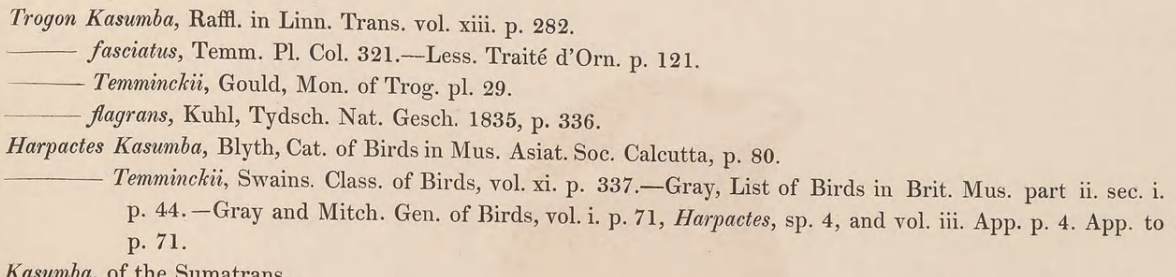

Kasumba, of the Sumatrans.

Great confusion respecting the name of this species has existed from the days of the lamented Raffles to the present time, and instead of its being cleared up, it would seem to have been added to by every writer who has had occasion to mention the bird; I myself, among others, have fallen into error on the subject; and even Mr. Blyth, after enumerating it under the name of Kasumba in his "Catalogue of the Birds in the Museum of the Asiatic Society of Calcutta," states in an appendix that perhaps that name ought to give place to that of Kondea, which name, I may remark, would seem not to be a scientific appellation, but merely a trivial one applied to specimens in the Paris Museum. It will be seen that I have retained that of Kasumba, which I think it likely was the one first assigned to it.

The countries inhabited by this species are Malacca, Sumatra, and Borneo, from all of which I have specimens in my own collection.

In a letter lately received from Mr. Wallace, now (1856) engaged in exploring the Islands of the Indian Archipelago, that gentleman, writing from Singapore, says, "You will think I have forgotten to write to you about the Trogons, but I have not neglected the subject. I remained two months on this island, where the jungle is now only to be found in small patches, but did not meet with any, and I doubt if there be a Trogon in the island. At Malacca, however, from whence I have just returned, I met with them. I think there are four species, but as I only obtained males of three, I cannot be certain. Two are of an ordinary size, and two are smaller. One of the larger I take to be Harpactes Kasumba: I send you a coloured sketch of the soft parts that you may make a correct drawing for your work. The habits and economy of the Indian Trogons assimilate closely to those of the American."

As nothing can exceed the beauty of this noble bird, the appearance the males must present in their native forests cannot fail to be attractive in the extreme, especially when the rich scarlet colouring of their breasts is contrasted with the equally brilliant green of the luxuriant vegetation of Malacca.

The sexes present a marked difference in the colouring of their plumage, as will be seen on reference to the opposite Plate, where they are accurately depicted.

I believe that the habits of the Harpactes Kasumba are somewhat solitary, and that the bird seldom quits the secluded parts of the forests which are its favourite place of resort.

The male has the head, throat and chest jet-black; breast, abdomen, and under tail-coverts deep rose-red, separated from the black of the chest by a crescentic band of white; from below the eye round the back of the neck a narrow band of red; back and upper tail-coverts yellowish brown; wings black, the coverts and tertiaries transversely rayed with fine irregular lines of white, and the shafts of the primaries white at the base; two middle tail-feathers chestnut-brown, tipped with black; the two rest on each side wholly black, the remainder black at the base, and white for the rest of their length, with dark shafts ; orbits light violet-blue, becoming of a more fleshy hue near the eyes; bill blue; gape light violet-blue; irides dark brown; feet brown.

The female differs in having the head and throat greyish brown instead of black; in the white band on the breast being much less conspicuous, the under surface sandy brown; and the markings of the wings bolder, and of a sandy hue, instead of pure white ; in other respects she is very similar, but the colours are less brilliant.

The Plate represents the two sexes of the size of life. 


\section{$2 \mathrm{BHL}$ Biodiversity Heritage Library}

Gould, John. 1856. "Kasumba Trogon, Harpactes kasumba [PI. 74]." The Birds of Asia 1(VIII), -. https://doi.org/10.5962/p.323354.

View This Item Online: https://www.biodiversitylibrary.org/item/115342

DOI: https://doi.org/10.5962/p.323354

Permalink: https://www.biodiversitylibrary.org/partpdf/323354

\section{Holding Institution}

Smithsonian Libraries

\section{Sponsored by}

Smithsonian Institution Libraries

\section{Copyright \& Reuse}

Copyright Status: Not in copyright

This document was created from content at the Biodiversity Heritage Library, the world's largest open access digital library for biodiversity literature and archives. Visit BHL at https://www.biodiversitylibrary.org. 